OPTIMUM. STUDIA EKONOMICZNE NR 5 (77) 2015

Igor YEGOROV ${ }^{1}$

DOI: $10.15290 /$ ose.2015.05.77.10

\title{
INNOVATION POLICY AND IMPLEMENTATION OF THE TRIPLE HELIX CONCEPT IN UKRAINE
}

\begin{abstract}
Summary
Ukraine is suffering from low level of innovation activities and widening gap between the industry and research institutions, both in government and higher education sectors. This is reflected in shrinking of R\&D financing, declining share of a number of graduates in natural sciences and engineering and some other indicators. Orientation on development of traditional industries of the national economies, such as metallurgy, basic chemicals and agricultural products prevents the country from focusing on knowledge production sectors. Lack of demand for R\&D results widens the gap between the remaining R\&D establishments and the industrial enterprises. Ukrainian state innovation policy has not changed substantially in recent years. Up to now, the main focus of government policy mix is on direct support of innovation in the form of (partial) financing of S\&T programs and provision of direct financing to selected innovation projects. The gap between the higher education sector and the industry is substantial. Current legislation does not allow universities or research institutes to be founders of a spin-off company with non-state ownership in Ukraine. At the same time, it is evident that problems of innovation development could be solved only within broader context of transformation of the national economy. Implementation of the Triple Helix (TH) concept for transformation of the Ukrainian national R\&D and innovation system could open new opportunities for its development.
\end{abstract}

Key words: innovation policy, $\mathrm{R} \& \mathrm{D}$, technoparks, triple helix model, universities

\section{Introduction}

In recent decades, a number of concepts of national innovation systems were evolved to open the way for complex studies of the industrial and S\&T systems in different countries. Triple Helix (TH) concept possesses an important place among them as it opens the way for comprehensive analysis of not only industrial sector and government sectors, but also for studies of interrelations between them and the universities. In reality, universities and other learning institutions play crucial role in the process of innovation development and growth of competitiveness of the national economies.

Introduction of new technologies and growth of competitiveness are interrelated processes, with technological advance is the central driving force behind economic

\footnotetext{
${ }^{1}$ Professor Igor YEGOROV - Department of Innovation Policy and High Technologies, Institute of Economy and Forecasting, National Academy of Sciences of Ukraine, e-mail: igor_yegorov1@ ukr.net.
} 
growth [Nelson, Nelson, 2002]. However, it is difficult to determine these connections quantitatively in terms reasons and results [Dosi, Teece, eds., 1997]. At the firm level, final success depends not purely on 'technological' factors but also on organizational framework of the company, situation in the market, sector specificity and so on. In general, higher innovativeness is associated with higher competitiveness. So, in 1990-2000 s, the share of innovative enterprises in Ukrainian economy was between $6 \%$ and $20 \%$, while in neighbouring Poland it was at least two times higher [Innovation in the Polish Economy..., 2010]. These figures correlate with all major indexes of competitiveness for national economies, which are used for international comparison. However, the level of innovativeness could not be itself an indicator of commercial success.

In conditions of growing role of knowledge in modern economy, companies are modifying their businesses with the aim to increase 'intellectual' components in their assets and to strengthen their ties with universities. In general, intellectual assets are playing a growing role in production processes, especially in hi-tech sectors. This requires new technical skills and managerial capabilities for successful development. Modern firms have to have substantial in-house capacity to recognize, evaluate, negotiate, and finally adapt the technology potentially available from different sources.

In the EU, the innovations are among key priorities of the development [Innovation Policy in Europe, 2008]. Co-operation in S\&T and innovation and R\&D have strong support among European population. Innovation is considered as a key element of mordernisation of the European economy and a major factor of competitiveness of the EU industry [Hashi, Welfens, Wziatek-Kubiak, 2007].

On the other hand, post-Soviet countries, including Ukraine, are suffering from low level of innovation activities and widening gap between the industry and research institutions, both in government and higher education sectors. This is reflected in declining (or stagnant) share of R\&D financing from the side of industry, shrinking civilian $\mathrm{R} \& \mathrm{D}$ in business sector, declining share of graduates in natural sciences and engineering and some other indicators.

It is evident that the Triple Helix (TH) concept is a useful instrument for analyzing current situation within Ukrainian innovation system thanks to its universalism and flexibility [Etzkowitz, Ranga, 2012]. However, it is worth to stress that the TH concept has found its interesting transformation in the publications of the Russian and Ukrainian authors in recent years. Analyzing the processes of creation and development of the national innovation systems in these countries some of them propose to consider incomplete TH models, which describe the situation in these countries more adequately. Thus, TH model transforms into several different "double helix" models of co-operation between different sectors of national economies [Dezhina, Saltykov, 2006]. This approach reflects serious difficulties with innovation policy in the biggest post-Soviet states and certain fragmentation of the innovation systems. As a result, we will consider relations between the government and industry and the government and universities independently to some extent in this article. We will also pay attention to the state research sector, which constitutes an important part of the national innovation system of the country. 


\section{Development of the innovation system in Ukraine in recent years}

Almost all Ukrainian governments in the last decade have declared their intentions to support innovation development and to stimulate structural changes in the national economy to make it more innovative and competitive. However, lack of economic reforms and orientation on development of traditional industries of the national economies, such as metallurgy and fuel production prevents Ukraine from focusing on knowledge production sectors. Lack on demand on R\&D results widens the gap between the remaining R\&D establishments and industrial enterprises.

In 2000-2008 the country has demonstrated substantial economic growth with the average annual level of approximately $7 \%$. Slowdown in the world economy in the second half of 2008 and in 2009 had serious impact on the Ukrainian economy, country's GDP declined by more than $14 \%$. A lot of Ukrainian enterprises had to stop their production. Some sectors have declined by more than a third during 2008-2009. Crisis created great problems in the financial sphere, especially for heavily indebted private companies, which reduced their R\&D budgets substantially. In 2013, the country's GDP had not reached the pre-crisis level. In 2014, after political crisis, GDP plunged again to the new 'bottom' level, and in 2015 the decline by another 9\% is expected. Innovation activity has dropped simultaneously.

The Ukrainian economy has clear export orientation but the bulk of the exported products are ferrous metals, basic chemicals and agricultural products with low level of value added. Technological modernisation was not a priority for Ukrainian business leaders. In recent years these sectors were indirectly subsidized through the system regulated prices for the input products (especially gas and energy), high artificial employment level and so on, while innovation companies had no special incentives to introduce new products and processes. Active collaboration with foreign companies can be an important ingredient of successful enterprise restructuring, particularly when competitive technologies are closely held, when export marketing links are crucial, or when outside methods and accountability are needed.

The decisions of the previous Ukrainian governments to preserve some high-tech industries under the state control (space and aviation are the most vivid examples) at the initial stages of reform are a clear example of such behaviour. In other sectors the government had intentions to provide selective support for a relatively small number of foreign companies. Very often the reasons for such support were not clear enough or some state officials preferred to arrange deals with one or two foreign partner on non-competitive basis. Internationalization of production in modern economy requires competitive strategies that are coherent in the face of powerfully supported international rivals, and generally requires reliable allies. This also requires creation of equal opportunities for different companies from the side of the state, as well as support of innovative companies are key precondition for successful restructuring and further development. The last evaluation of the Ukrainian innovation capacities on the base of indicators of the European Innovation Scoreboard was made in 2011 and it showed, that the country was lagging behind of the EU states and some its non-EU neighbours (see picture 1). 
CHART 1.

The place of Ukraine according to the value of SII (in comparison with selected EU countries), 2008-2010

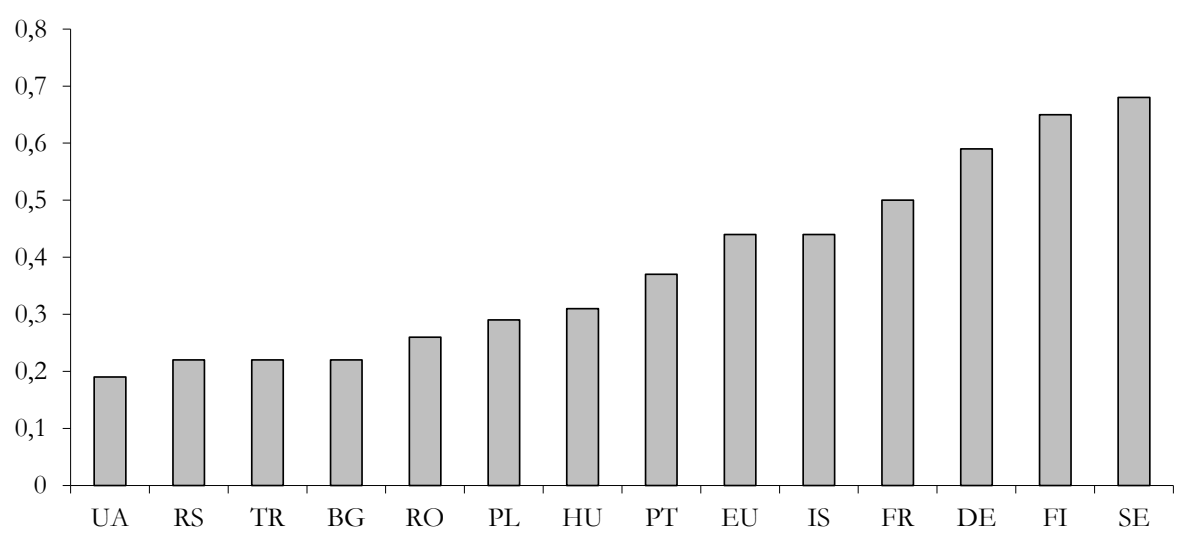

Legend: UA - Ukraine, RS- Russia, TR - Turkey, BG - Bulgaria, RO - Romania, PL - Poland, HU - Hungary, PT - Portugal, EU - average figure for the EU countries, IS - Spain, FR - France, DE - Germany, FI - Finland, SE - Sweden

Source: [Enhance Innovation Policies..., 2011].

It is important to stress that Ukraine had high marks for the level of education of population and some relative financial indicators, such as share of expenditures on IT in GDP, but the country demonstrated poor performance in patent statistics and innovation support policy. The problems of the R\&D in Ukraine developed over many years and have now reached such proportions that neither quick nor inexpensive solutions are feasible. The challenge to government policy in the S\&T area is how to mould the remaining national research capabilities into a pattern that will contribute more effectively to the processes of economic recovery. For the time being, however, R\&D 'assets' are considered largely as a liability.

At the same time, in some cases, research institutes and design bureaus in Ukraine contain the results of R\&D, which represent a potential of millions of dollars in commercial value. However, technologies for domestic development and technologies and products ready for competition in the world market are different things. Anyway, there is a potential opportunity for establishing more 'balanced' relations with Western partners in these cases. Some leading research institutes have already transformed themselves into research- production companies, with preservation of some R\&D and creation a dozens of spin-offs that are doing business, including production of goods, on the base of former institutes. Such examples are not numerous among technologyoriented institutes in Ukraine. Very often these companies could not overcome relatively high entry barriers that exist in foreign markets, especially in developed countries. Costs, related to patenting, marketing and dissemination of their products appear unacceptable 
in many cases. So, they are moving to the emerging markets of South-East Asian countries, Iran and some other states. However, such strategy could not be considered as a long-term one. Situation in the lowest segments of the market is usually strain and unstable. To be competitive companies have to try to enter the largest and the most sophisticated markets.

Decline of R\&D financing in 1990s-2000s, when almost all research budgets were spent on wages and on bills for utilities has led to the situation, when the share of modern research equipment has shrunk by several times in many research institutes. About halve of all equipment could be written off balances of research institutes according to existing rules but this equipment has no adequate substitution [Yakubovskii, 2009]. Some institutes had to stop regular scientific experiments, needed for undertaking research programs. For example, the only experimental reactor in the Ukrainian Institute for Nuclear Physics was terminated in the first half of 1990s thanks to lack of funds to cover electricity bills. Since this time, Ukrainian nuclear physicists had very few opportunities to check their theoretical results. Similar situation was in the other natural sciences' institutes. This means that Ukrainian scientists had limited opportunities to obtain new competitive results. However, sometimes, it is possible to work in the Western countries due to special research schemes, which were introduced in 1990s-2000s within Framework programmes and other initiatives.

It is also important to stress that in the 1990s-2000s numerous mechanisms of business support were created with the state participation. In principle, they could be used to support innovation and research activities. Total number of business centres and business incubators is about 500 . However, very few of them work effectively. The problem is that almost all types of business support organizations, with the exception of three technoparks were not oriented towards supporting innovation development (these three only out of 16 were related to innovation and R\&D activities).

Up to now, the main focus of government policy mix is on direct support of innovation in the form of (partial) financing of $S \& T$ programs and provision of direct financing to selected innovation projects. Till the 2005, techoparks had some tax incentives for stimulating innovation activities but the abolishment of these incentives in early 2005 led to stagnation of technopark's development. In Ukraine, other mechanisms for supporting innovation enterprises are underdeveloped and they are often used in a pervasive way. So, in Ukraine in 1990s, almost all money from the specially created State Innovation Fund was spent on projects, which were not related to development of innovation businesses or technology transfer.

On the other hand, there are several 'ministerial' systems of organisations, which could be used to develop the system of innovation support. The Ministry of Education and Science has special centres of S\&T information in almost every Ukrainian region (oblast). The biggest centre in Kiev has up to 100 employees. It collects information from local centres on all registered $R \& D$ projects and has to disseminate useful information on promising $\mathrm{R} \& \mathrm{D}$ results and innovation. The centres are more successful in undertaking the first task.

The most important barrier to innovation activities in Ukrainian enterprises is the lack of financial resources. Enterprises rarely use bank loans to finance innova- 
tion activities as the interest rate is prohibitively high. It varied between 15 and $25 \%$ in 2006-2012, depending on the currency of the loan. Institutional barriers are also important, as well as a lack of demand in internal market. A number of venture capital funds were created in Ukraine under the special law in mid-2000s. However, their resources were exclusively used in the construction sector to finance boom in the property market. There is no information about support of innovation projects from the side of these funds. The State Agency of Ukraine on Investment and Innovation (SAUII) has prepared a draft of new law on venture funds to direct financial resources into innovation sphere in 2008. The new law has to install barriers for the utilization of 'innovation' money on other purposes. Unfortunately, this draft has not been considered by the Parliament in recent years.

Ukraine has initiated several innovation-related programs in the past. Most of them had disciplinary orientation on development of specific products, such as new computers or medicine. At the same time, some programs were formed as 'organizational' ones. So, in 2008-2009 the Ukrainian government developed and approved two state goaloriented programmes. The first is a Programme of the development of the system of information and analytical support of state innovation policy implementation. The key objective of the Programme is monitoring of innovation development of the Ukrainian economy. It was designed for three years with a total budget of $10.5 \mathrm{~m}$. Hr. The key idea of the Programme was to create effective instruments of monitoring of the state innovation policy at the level of central government and on the level of regions. Initially, there were plans to establish special groups at the state and regional levels, which could collect data, conduct surveys and prepare analytical materials on the situation in the innovation sphere. These groups had to work under the guidance of the Ministry of Economy of Ukraine. The second programme is the Programme of creation of innovation infrastructure in Ukraine. It was designed for five years with the budget of $280 \mathrm{~m} \mathrm{Hr}$. Ukr. It is assumed that the Programme will receive financing from different sources: from the state budget $(104 \mathrm{~m}$ Hr.), local budgets (about $80 \mathrm{~m} \mathrm{Hr}$ ), and other sources (private business and international donors - $96 \mathrm{~m} \mathrm{Hr}$.). The government hoped to attract investors to create technology transfer centres for small businesses within this Programme. Private companies could benefit from using the newly-created elements of infrastructures by provision of different services and products to innovation companies and by obtaining some privileges, including access to cheaper (subsidised) bank loans, information and expertise from the state research centres. Unfortunately, both programs had no proper financial resources in 2009-2012 and they were terminated in 2012-2013.

However, some programs were more successful. So, the Ukrainian Parliament has passed the new State Goal-oriented Space Program for 2013-2017. This Program is the fifth such program in Ukrainian history since 1992. The main aim of the program is to integrate activities of enterprises and research institutes in the space sector and to utilize R\&D results more effectively up to the needs of sustainable development and national security. The program includes eight subprograms (similar to the previous ones), aimed at development new satellites for communication and the research of the Earth from 
the space; further development of infrastructure; experimental projects on new space technologies; and joint commercial projects with other countries, first of all - the USA, EU countries, Brazil, Russia and some others. Ukraine has substantial S\&T potential in certain important space technologies but during the economic crisis of the 1990s the country lost some of it. Now the country has to utilize more effectively the existing capabilities and has to develop new technologies and products to be involved in international efforts in space research and commercial exploitation of space technologies. In fact, it is very difficult to conduct space projects without co-operation with key international players in this area. That is why such co-operation is foreseen in the Program. However, in conditions of conflict in the East of the country and worsening of relations with Russia, perspectives of the implementation of the program look modest.

At the same time, it is important to stress, that problems of the R\&D and innovation in Ukraine have developed over many years and they have now reached such proportions that neither quick nor inexpensive solutions are feasible. The challenge to government policy in the S\&T area is how to mould the remaining national research capabilities into a pattern that will contribute more effectively to the processes of economic recovery. For the time being, however, R\&D 'assets' are considered largely as a liability. It is evident that the growth of R\&D expenses itself could not solve institutional problems that exist in Ukraine. Despite official support for 'national science,' the R\&D sector is not a focal point of economic policy in Ukraine. Different laws are not properly coordinated as they are prepared by different interest groups. The most vivid examples are related to the permanent conflicts between the Ministries of Finances and the Ministries, which are responsible for S\&T. For instance, in Ukraine, thanks to superiority of the Budget law over all other laws, the Ministry of Finance blocks all initiatives, aimed at support of $\mathrm{R} \& \mathrm{D}$ and innovation activities. The main reason for this blockade is the hypothetical possibility of the state income decline. Calculations of indirect benefits (in the form of new working places, growth of export and so on) are not taken into account.

\section{Key features of the transformation of Ukrainian research system}

Branch institutes had leading positions in the Ukrainian research system in the past. In some cases, the collapse of the old branch structure of the Soviet-type economy led to the development of new links between research institutes and industrial firms and, especially, to the development of direct links with foreign companies. At the same time, the changing boundaries between private and public sectors led to new, nationally specific systems of innovations.

One might expect that some applied research institutes and design bureaus were transformed into relatively small research or production companies and science-based SMEs. However, their future depends heavily on the speed of economic transformation in key manufacturing industries. If Ukrainian manufacturing enterprises develop better access to international markets and strong ties with foreign partners, this will have 
an obvious and positive effect on industry-oriented R\&D institutions. Without clear signals from the industry in the form of new orders and, in some cases, without sufficient financial support, research institutes will be unable to retain their best staff or to update their technical base.

In contrast with the branch institutes and design bureaus, research institutes of the Academy of Sciences in Ukraine rely on the state budget as the main source of their financing. They receive approximately three quarters of their funds directly from the state. This level of financing does not guarantee effective development but provides basis for survival of research institutes. In recent years, the number of employees in the Academies has stabilized, while the number of research institutes doubled. The share of the Academies of Sciences in the total financing $\mathrm{R} \& \mathrm{D}$ and the share in the total number of employees in research sector have increased in recent years [Yegorov, 2009].

There are more than 300 universities in Ukraine. More than two thirds of the country's doctorate holders are working there. However, contribution of universities into R\&D activities remains relatively small. Universities received $5-7 \%$ of all $R \& D$ funds in recent decade. The higher education sector and the private non-profit sector have not plaid a significant role in the R\&D financing both retrospectively and in the current period. The higher education sector as an executing agent of R\&D is still extremely dependent from the state financing (the range of the state funds was $68.7 \%-74.7 \%$ of the total financing of the universities in the last two decades).

The gap between the higher education sector and the industry is substantial. Current legislation does not allow universities or research institutes to be founders of a spin-off company with non-state ownership in Ukraine. At the same time, it is evident that problems of innovation development could be solved only within broader context of transformation of the national economy. Another factor, that has negative impact on innovation, is the armed conflict in the East of the country: Ukrainian authorities simply are not focusing on non-military issues.

Universities are trying to change the situation. On December 20 $0^{\text {th }}, 2006$ special Law on scientific parks passed through Parliament. The key feature of this law is that it does not contain norms, aimed at obtaining specific financial incentives for parks. There were plans to create a number of such parks within the country's technical universities. However, economic crisis of 2008-2009 has ruined these plans. Very few scientific parks have been created in Ukraine since this time. The most well-known of them is the Kiev Polytechnic Institute (University) Science Park in Kiev. The University tries to implement the idea of Triple Helix at different stages of its functioning. Initially, the park was created as a part of the EU-sponsored Tacis-Tempus project (2004-2006), aimed at bridging the gap between the universities and business. The University and its partners have created 5 special foundations to provide financial resources for the innovation projects. Students spend up to $30 \%$ of their learning time on innovation studies. Special 'start-up' school has been created too. In 2014, rector of the University expressed an opinion, that only $10 \%$ of students could be entrepreneurs but the knowledge of innovation processes is useful for all graduates. More than 110 start-ups have been created in this science park, and more than 150 different products have been commercialized. Total financing from business reached 23.4 million Hr. in 2014. 
University has plans to build special Science City with approximately 5500 employees and 170 million USD of investment [Bazhal, 2015]. Another model is used by the Science Park in Kiev Shevchenko University. This park has five different stakeholders, including another university and 3 research institutes of the National Academy of Sciences. However, this park was not so successful, as previous one.

Ukrainian universities should be given a certain degree of financial autonomy. This will allow them to perform quickly certain financial transactions and to avoid long bureaucratic procedures, which are used by the Treasury of Ukraine. An additional incentive for commercialization could be a granting the universities rights to distribute funds, derived from contract research, as well as to utilize revenues from the licensing of intellectual property. According to international practice, such steps are usually aimed at creating and improving university technology transfer centers, to support research and development international projects, upgrade technological support, etc.

A greater degree of autonomy of universities will allow them to use such source of commercialization of intellectual property as venture capital. Another source of funding is specialized investment funds, whose activities are concentrated in potentially profitable innovation projects. This practice is common in developed countries and it allows to receive substantial effect from scientific and technological development. On the practical side, the adoption of draft laws 'On venture funds of innovation development' and 'On venture investment companies' could give impetus to the revival of innovation sphere and to commercialization of scientific results in Ukraine, both for companies and for higher education sector.

In response to the challenges of modern times, the world's leading universities have felt the need of transformation - they turned to the powerful academic centers that produce new scientific development and training products in the future enter the market. These entrepreneurial universities represent an economic corporation that produces knowledge, and individual faculties have the opportunity to test their competitiveness in the market and receive from this income, which is aimed at the development of the university. Central to their work is technology transfer and commercialization of research results. As these universities interested in obtaining the maximum added value from the commercialization of its own technology, they contribute to the growth of the projects from an idea to a successful business or technological implementation [Excellence v Equity..., 2015]. Ukrainian universities have to follow this practice.

While the principles and practice of financial support of R\&D is of considerable concern, the aging of the research community, outflow of research personnel from $\mathrm{R} \& \mathrm{D}$ institutes and the obsolescence of their research equipment pose another threats to the future of R\&D systems in Ukraine. The bulk of researchers in Ukraine are of mature age (average age of Doctor of Sciences is over 61), and the opportunities for recruiting young scientists are very limited. Gifted young persons could chose between a research career in developed countries and work in business that brings much higher income than work in the national research establishments. The same applies to the aging of research equipment. It is clear that without remedial actions, the productivity of 
the system will continue to fall, with negative consequences for the economy as a whole.

Ukraine urgently needs not only a serious transformation within the S\&T system, but also important changes in their environment. So, the introduction of adequate legal protection for intellectual property rights, especially in foreign countries, is of critical importance for individual researchers, S\&T institutes and science-based SMEs. This is also very important for foreign companies seeking to engage in direct investment or some other form of business alliance, and for domestic companies that co-operate with them.

\section{Cooperation with the EU countries and its impact on the transformation of research system in Ukraine}

In 2002, Ukraine signed an agreement with the EU on S\&T co-operation, including basic and applied research and technology development. Key thematic areas of cooperation were also determined. They comprise environmental and climate research, including observation of the Earth's surface; biomedical research and health protection; agriculture, forestry and fishery; industrial technologies; material science and metrology; non-nuclear power engineering; transport; information society technologies; social research; S\&T policy studies; training and the exchange of specialists. This agreement supplemented earlier documents that were signed in the 1990s (The Agreement on Partnership and Collaboration between Ukraine and the EU and some others), opening the way for co-operation between Ukraine and the EU in different areas of science and education (programmes such as Tacis-Ace, Tacis-Tempus and INTAS).

In 2005, Ukraine and the EU signed an Action Plan, containing important references to the need to develop co-operation in R\&D. The Action Plan was an important component of the European Neighborhood Policy Initiative (ENPI). Recently the Ukrainian Parliament has approved an official Ukrainian application to Eureka. Ukraine has a number of bilateral agreements on S\&T co-operation with individual EU countries, which complement the main agreement with the EU. In recent years, all Ukrainian governments have announced their intention to develop closer relations with the EU, and European Union policy has a strong influence on formulation of science policy in Ukraine.

Ukraine concluded a new agreement with the EU on S\&T co-operation in 2010, which was implemented in 2011. It could open new opportunities for co-operation and it creates framework conditions for a number of joint initiatives. Bearing in mind the intention of the country to join the EU in the future, the Ukrainian authorities are interested in harmonisation of national research policy with EU policy. The Research Framework Programmes, which bring together research organisations from EU member-states, is one form of co-operation that has become available for Ukraine since the early 1990s, during the Third Framework Programme (FP3), when an agreement for partnership and collaboration was signed between Ukraine and the EU. The country signed an agreement on association with the EU Horizon-2020 program 
in March, 2015. This opens the way for more active co-operation with the EU countries in R\&D in the near future. The impact of the participation in the EU FPs is definitely positive, as Ukrainian scientists receive valuable new experience and knowledge, and strengthen their contacts with western partners. On the other hand, this impact is limited as the number of participants is not high. Co-operation between Ukrainian and EU researchers remains relatively low. Additional support from the Ukrainian government for the promotion of FP activities is needed as well as additional links between Ukrainian researchers and their EU counterparts to forge partnerships in future projects. Support for capacity- building measures in research and innovation through ENPI could help in this regard. As a non-EU member, Ukraine cannot participate (at least, as a leading partner) in some FP-related initiatives. Another problem is that existing internal taxation practices do not support international project implementation, despite there being some clauses in EU-Ukraine agreements on special financial conditions for $\mathrm{R} \& \mathrm{D}$ projects. This creates serious barriers for co-operation.

There is no direct influence of the EU Programme on priority-setting in Ukraine, although the Ukrainian policy-makers study the content of the FPs attentively and the results of these studies are used to formulate research agendas in different ministries, universities and state academies of sciences [Zinchenko, 2013]. As to the results of the previous co-operation programs, they are analyzed in one of our paper, published recently [Yegorov, Ranga, 2014].

\section{Conclusion}

In general, $\mathrm{R} \& \mathrm{D}$ and innovation sectors in Ukraine remain unreformed and underutilized. It is evident now that lessening state control over the process of transition is not having the desired effect in many cases, especially in transforming the R\&D system. Weakness and uncertainty of S\&T policy has conspired with the economic crisis to inflict losses in terms of manpower and technical assets in Ukraine, and indeed to produce unfavourable structural changes. The crisis in Ukraine could be solved only by co-ordinated efforts on the part of the state and scientific communities. The challenge to government policy in the S\&T area is how to mould the remaining national research capabilities into a form that will contribute better to the process of economic recovery and further development. For the time being, however, R\&D 'assets' are viewed largely as a liability. This is partly the result of structural and organisational mismatches, and partly because of their low immediate relevance to market realities. Creation of favourable conditions for science-based SMEs could help to solve the problem of adequate utilization of intellectual capacities of former scientists and engineers and it also could contribute to the positive structural changes in the national economies, which have high shares of traditional heavy industries.

The transformation of national innovation system with special attention to cooperation between enterprises, state research institutes and universities is critically important for the country. Ukraine needs much more institutions that would have potential to finance innovation sector. These institutions have to accept high level of 
risks for high potential profits and the same time, they will not require collateral, nor charge interest payments. It would be also important to provide not only short-term, but also long-term and at least medium term loans and to contribute to boost innovation activities. As to the business environment, it is very useful to create conditions, where entrepreneurs will be willing to sell significant part of their shares to outsiders and also they will be willing either to be acquired or to participate in public offerings. Labour market has to be sufficiently flexible, as top quality managers and technologists will be available to staff of growing firms.

It is evident that, at the current stage of development, it would be extremely difficult to obtain financing for innovative enterprises from private sources in Ukraine. That is why the state has to play more active role in stimulating creation and development of such cooperation within the national innovation system in Ukraine. In some cases, even such mechanisms as long-gestation projects, involving basic research with the state support could be justified. There is a plethora of different types of incentives, which government could use, including financial and fiscal incentives, direct lending programmes and so on. The problem lies in choosing right combination of these incentives, as government involvement easily creates market distortions, cause problems of moral hazard and adverse selection.

The government has to accept that innovative enterprises and research institutes need special treatment and it has to develop mechanisms, aimed on their support. This will have positive impact on industrial structure and the general economic indicators, as such enterprises usually have better cost structure and higher value-added than noninnovative enterprises. Programs on supporting dissemination of innovations in industrial companies have also to be initiated. Absolute majority of these companies have no enough knowledge about the best practices in their industries, nor enough resources to introduce innovations. Utilization of modern technologies and switching to new products could lead to substantial growth of productivity and positive changes in other economic indicators.

Bearing in mind rapid changes in technology and markets and the increasing focus on exports, banks, private venture funds and state organizations have to develop specific expertise in project evaluation. Existing technologies and know-how could be commercialized, and bring substantial dividends to the countries in transition. At the same time, technology transfer from the West could help to solve not purely economic, but in some cases, severe environmental and social problems, from which Ukraine is suffering, too.

Special attention has to be paid to the development of cooperation with the EU states. This cooperation brings important expertise in the most advanced areas, and it will help to compensate above-mentioned shortcomings of the national innovation system of Ukraine. In terms of TH model, this cooperation will be important for transformation of existing 'partial' ('dual') 'sub-models into functioning three-part model, which is common for developed countries. Some preconditions for widening of such cooperation are in place, as Ukrainian researchers are trying to take part more actively in the EU scientific initiatives. It is important now to attract Ukrainian companies to joint innovation projects. At the same time, the level of coordination of innovation and science policies with the EU programmes has to higher. In this case the chances of 
success could rise, as the some Ukrainian neighbours from Eastern and Central Europe have demonstrated.

\section{References}

Bazhal Yu. 2015 Rozvitok innovatsinnoi diyalnosti u trikutniku 'derş̧ava-universiteti-promislovist', "Ekonomika i Prognozuvannia", N. 1.

Dezhina I., Saltykov B. 2006 Instrumenti stimulirovania komertsializatsii NIOKR, Working Paper N72, Institute of Transformation Period, Moscow.

Enhance Innovation Policies, Strategies and Regulation in Ukraine, 2011, (eds.) G. Strogilopulos, G. Rumph, I. Yegorov, EuropeAid Project 127694/C/SER/UA, Fenix, Kiev, vol. 3.

Etzkowitz H., Ranga M. 2012 The Great Expectations: the Innovation Solutions to the Contemporary Economic Crisis, "Social Science Information", vol. 51, N. 2.

Excellence v Equity. Special Report: Universities, 2015, “The Economist”, March 28.

Industrial Competitiveness and Restructuring in Enlanged Europe, 2007, I. Hashi, P. Welfens, A. Wziatek-Kubiak (eds.), Palgrave-Macmillan, London, N.Y.

Innovation in the Polish Economy in Transition: Selected Economic and Managerial Issues, 2010, A. Jasinski (ed.), University of Bialystok, Bialystok.

Innovation Policy in Europe, 2008, C. Nauwelaers, R. Wintjes (eds.), Edward Elgar, N.Y. and Cheltenham

Nelson R., Nelson K. 2002 Technology, Institutions, and Innovation Systems, "Research Policy", vol. 31.

Technology, Organization and Competitiveness: Perspectives on Industrial and Corporate Change, 1997, J. Dosi, D. Teece (eds.), Oxford University Press, Oxford, UK.

Yakubovskii M. 2009 Naukovo-metodichne zabespechennia modernizatsii Uukrainskoi promislovosti, "Ekonomika Ukraini”, N. 10.

Yegorov I. 2009 Post-Soviet science: Difficulties in the Transformation of the R\&D Systems in Russia and Ukraine, "Research Policy", v.38, issue 4.

Yegorov I., Ranga M. 2014 Innovation, Politics and Tanks: the Emergence of a Triple Helix System in Ukraine and the Influence of EU Cooperation on its Development, "Int. J. Transitions and Innovation Systems", Vol. 4, No. 3.

Zinchenko N. S. 2013 Ukeraina u ramkovih programah EC: djsvid i perspektivi, "Problemy Nauki", N. 2. 